\title{
Influence of Work Environment Noise to Productivity of Employee Performance of Sidoarjo District
}

\author{
Agustina Astri Cahyani' ${ }^{1}$, Zufra Inayah, SKM., M.Kes \\ College student, Department of Public Health, Health Faculty, Gresik Muhammadiyah University, Indonesia \\ Lecturer, Department of Public Health, Health Faculty, Gresik Muhammadiyah University, Indonesia
}

\begin{tabular}{l}
\hline Article Info \\
\hline Article history: \\
Received Jun 9, 2019 \\
Revised Nov 20, 2019 \\
Accepted Feb 11, 2020 \\
\hline
\end{tabular}

Keywords:

Noise,

Work

Environment,

Performance Productivity

\begin{abstract}
Employees of the Sidoarjo Regency Health Office have a great responsibility in developing and improving health, especially in Sidoarjo Regency but the location of the Sidoarjo Regency Health Office is less strategic because it is located in the center of the traffic crowd which has an impact on employee performance. This study aims to analyze the noise of the work environment on the productivity of the performance of the employees of the Sidoarjo Regency Health Office.
\end{abstract}

This research was observational analytic type. The sampling technique in this study used total sampling, as many as 30 people. The instruments of this research were questionnaire and sound level meter.

Data analysis techniques include editing, coding, data entry, and conducting univariate and bivariate analysis techniques.The results of this study are: the majority of Sidoarjo Health Office employees experience high noise with an average noise intensity of $71.01 \mathrm{dBA}$; most employees of the Sidoarjo Health Office (56.7\%) had good work productivity; and there is an influence of environmental noise on employee performance productivity Sidoarjo Health Office with a $p_{\text {value }}$ of $0.020<0.05$.

To improve employee productivity, employees of the Sidoarjo Health Office are expected to submit noise complaints to the leaders of the Sidoarjo Health Office so that they can be addressed immediately and arrange sitting positions while working away from sources of noise and the Health Office is expected to be able to monitor the noise levels of the workspace of employees and immediately make efforts to reduce employee room noise.

Copyright $@ 2020$ University Muhammadiyah of Gresik. All rights reserved.

\section{Corresponding Author:}

\section{Agustina Astri Cahyani,}

College student, Department of Public Health, Health Faculty,

Gresik Muhammadiyah University,

Street Sumatera 101 Gresik Kota Baru (GKB), Gresik - 61121.

Email: agustina@gmail.com 


\section{INTRODUCTION}

Employees are the main source of an organization that cannot be replaced by other resources, because no matter how good an organization, complete facilities and facilities will not be useful without having employees manage, use and maintain it. The success of the agency in achieving its goals is one reflection of an effective and efficient organization. How well employees perform their work significantly influences organizational productivity and performance. There are three main factors that affect how existing individuals work. These factors are the ability of individuals to do work, the level of effort expended, and organizational support [1].

Civil servants or State Civil Apparatus (ASN) as government apparatus and as public servants are expected to always be ready to carry out their duties properly and ready to serve the community well. The implementation of duties and work in general is an obligation for employees in the organization. Civil servants are required to always work with high enthusiasm so that in providing services to the community does not seem slow, lazy, and reluctant. The spirit of work for civil servants is needed to improve services to the community so that its quality as the main resource in the agency appears. The quality of human resources can improve the progress of an agency. In an effort to improve the quality and ability of human resources needed a careful planning and strategy with planned and organized activities so that everything can run smoothly [2].

Employee performance in the organization is the answer to the success or failure of organizational goals that have been set. According to [3] in Coaching for Performance, performance is the implementation of the functions required of a person or a company, an achievement, a general role skill.

The work environment is anything that is around workers that can affect themselves in carrying out the tasks that are charged, for example cleanliness, sound, music and others [4].

Sidoarjo Regency Health Office is one of the agencies engaged in the field of health with the task of running health affairs. This agency has a vision towards "Healthy Sidoarjo Independent and Fair". The mission of the Health Service is to drive health-oriented development, encourage the realization of community independence for a healthy life, realize, maintain and improve quality health services, equitable and affordable, increase efforts to control and overcome health problems and improve and utilize health resources [5].

Results of Performance Evaluation of Sidoarjo Regency Health Office Staff in 2017 and 2018

\begin{tabular}{|c|c|c|c|c|c|c|}
\hline Work Behavior & $\begin{array}{c}\text { Weight } \\
(\%)\end{array}$ & $\begin{array}{c}2017 \\
\text { Capation } \\
\text { Value }\end{array}$ & $\begin{array}{c}\text { Score } \\
(\%)\end{array}$ & $\begin{array}{c}\text { Weight } \\
(\%)\end{array}$ & $\begin{array}{c}2018 \\
\text { Capation } \\
\text { Value }\end{array}$ & $\begin{array}{c}\text { Score } \\
(\%)\end{array}$ \\
\hline Discipline & 10 & 80 & 8 & 10 & 75 & 7,5 \\
\hline Responsible & 10 & 80 & 8 & 10 & 75 & 7,5 \\
\hline Cooperation & 10 & 85 & 8,5 & 10 & 80 & 8 \\
\hline Leadership & 10 & 75 & 7,5 & 10 & 80 & 8 \\
\hline Work Quality & 20 & 85 & 17 & 20 & 75 & 15 \\
\hline Work Quantity & 20 & 85 & 17 & 20 & 75 & 15 \\
\hline Job Skills & 20 & 80 & 16 & 20 & 70 & 14 \\
\hline \multicolumn{3}{|c|}{ Amount } & 82 & & & 75 \\
\hline
\end{tabular}


The performance condition of employees at the Sidoarjo Regency Health Office has decreased from 2017-2018 in all aspects from $82 \%$ to $75 \%$. In mid 2017, the organizational structure in the Sidoarjo Health Office underwent a change so that there was also a change in the layout of the room in the field related to serving health personnel licensing which has its own building located close to the traffic center because it is directly adjacent to the west ring road and the station Pagerwojo.

\section{RESEARCH METHOD}

This research uses observational analytic research using a time approach. Based on the approach, this research uses a cross sectional approach. Cross Sectional Research is an approach to study the dynamics of the correlation between risk factors and ethics by means of an observation or data collection approach at one time [6].

The population in this study were employees of the Sidoarjo Health Office in the field of Health Resources totaling 17 people and in the field of Health Services totaling 13 people. The totals population is 30 people.

According to [7] the sample is part of the number and characteristics possessed by the population. The sampling technique in this study uses total sampling. Total sampling is a sampling technique where the number of samples is equal to the population [8]. Samples taken from this study were 30 people.

\section{RESULTS AND DISCUSSIONS}

\section{a. Noise Intensity Measurement in the Work Environment}

Noise intensity measurements are carried out in a room area Health Resources and Health Service Rooms. Based on the results measurement of noise intensity, the magnitude of the average noise intensity during 4 hours at 5 measurement points can be seen in the following table:

$\begin{array}{ccc}\text { No } & \text { Point of Measurement } & \text { Average Noise Intensity (dBA) } \\ 1 & 1 & 70,28 \\ 2 & 2 & 70,18 \\ 3 & 3 & 69,01 \\ 4 & 4 & 72,18 \\ 5 & 5 & 73,40 \\ & \text { Average } & \mathbf{7 1 , 0 1}\end{array}$

b. Distribution of average noise in the Health Care Room Sidoarjo Health Office

\begin{tabular}{ccc} 
No & Point of Measurement & Average Noise Intensity (dBA) \\
\hline 1 & 1 & 63,26 \\
2 & 2 & 65,74 \\
3 & 3 & 61,90 \\
4 & 4 & 65,90 \\
5 & 5 & 63,62 \\
& Average & $\mathbf{6 4 , 0 8}$
\end{tabular}


c. The magnitude of the average noise intensity in the Health Office Sidoarjo Regency when compared with Minister of Health Regulation Number 48 of 2016, can be seen in the following table:

\begin{tabular}{|ccccc|}
\multicolumn{1}{c}{ Location } & $\begin{array}{c}\text { Intensity } \\
\text { Noise }\end{array}$ & NAB & Information & $\begin{array}{c}\text { Amount } \\
\text { Employee }\end{array}$ \\
Room Resource Health & 71,01 & 65 & $\begin{array}{c}\text { Above NAB } \\
\text { (High noise) }\end{array}$ & $17(56,3 \%)$ \\
Room Service health & 64,08 & 65 & $\begin{array}{c}\text { Under NAV } \\
\text { (Low noise) }\end{array}$ & $13(43,3 \%)$ \\
& Totals & & & $\mathbf{3 0}(\mathbf{1 0 0} \%)$
\end{tabular}

The average noise intensity in the room Health Resources is above the NAV of $71.01 \mathrm{~dB}(\mathrm{~A})$ which is categorized high, while the average intensity the noise in the Health Services room is below the NAV which is $64.08 \mathrm{~dB}$ (A) which is categorized as low. Number of respondents in the room environment Health Resources as many as 17 people. while the number of respondents who are in the Health Service environment as many as 13 people. With Thus the majority of respondents in this study experienced noise high that is equal to $56 \%$, while a small portion ie $43.3 \%$ experienced low noise.

d. Employee Performance Productivity Rating

\begin{tabular}{clccc} 
No & \multicolumn{1}{c}{ Category } & Score & Amount (Employee) & Percentage \\
1 & Very bad & $30-47$ & 0 & $0,0 \%$ \\
2 & Bad & $48-65$ & 0 & $0,0 \%$ \\
3 & Enough & $66-83$ & 4 & $13,3 \%$ \\
4 & Good & $84-101$ & 17 & $56,7 \%$ \\
5 & Very good & $102-120$ & 9 & $30,0 \%$ \\
& $\quad$ & $\mathbf{3 0}$ & $\mathbf{1 0 0}$
\end{tabular}

e. Environmental Noise Against Employee Productivity at the Sidoarjo Health Office in 2019

\begin{tabular}{lcccccccc} 
& \multicolumn{4}{c}{ Noise } & \multicolumn{2}{c}{ Totals } \\
Productivity the performance & \multicolumn{2}{c}{ Low } & \multicolumn{2}{c}{ High } & & \% \\
& N & \% & N & \% & N & \% \\
Enough & 6 & 36,2 & 15 & 88,2 & 21 & 70,0 \\
Good & 7 & 53.8 & 2 & 11,8 & 9 & 30,0 \\
Very good & 13 & 100,0 & 17 & 100,0 & 30 & 100,0
\end{tabular}




\section{f. Fisher Test Results The Effect of Environmental Noise on Employee Productivity in Sidoarjo Health Office in 2019}

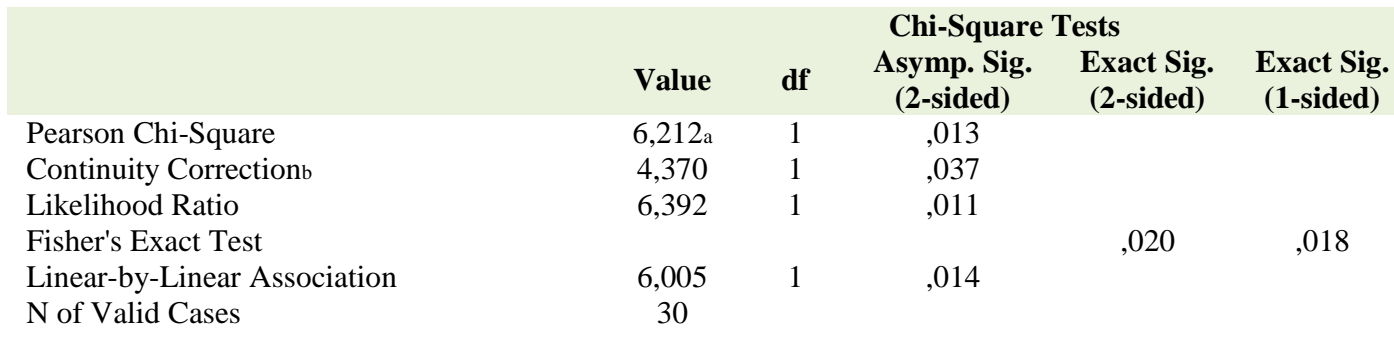

a. 1 cells $(25,0 \%)$ have expected count less than 5 . The minimum expected count is 3,90

b. Computed only for a $2 \times 2$ table

Fisher's test can be seen that the $\mathrm{P}_{\text {value }}$ at sig $0.05=0.020$ which shows a $\mathrm{P}_{\text {value }}$ $<0.5$ so that it can be stated that $\mathrm{H}_{0}$ is rejected and $\mathrm{H}_{1}$ is accepted, meaning that there is an influence between noise on employee performance productivity

\section{CONCLUSION}

The conclusions obtained from this study are:

a. Most of the Sidoarjo Health Office employees experienced high noise.

b. Most employees of the Sidoarjo Health Office have good performance productivity.

c. There is the influence of environmental noise on the productivity performance of the Sidoarjo Health Office employees

\section{SUGGESTION}

Suggestions obtained from this study are:

a. It is expected that Sidoarjo Health Office employees can proactively submit noise complaints experienced to the leaders of the Sidoarjo Health Office so that they can be addressed immediately and can anticipate noise by adjusting the sitting position when working that can stay away from sources of noise.

b. It is expected to be able to monitor the noise level of employees' workspaces and immediately make efforts to reduce employee room noise that can interfere with employee performance and productivity using sound dampers in the room, adjusting the location or position of the room far from the noise center.

\section{REFERENCES}

[1] Badri, Munir Sukoco. 2006. Modern Office Administration Management. Surabaya: Erlangga

[2] Daniel, T.W., J.A.Hlms, \& F.S Baker. 1992. Silvinatural Principles. Yogyakarta: UGM Press

[3] Dareho, M.P., Kindangen, P., \& Kojo, C. 2017. The Effect of Education, Training and Loyalty on Employee Performance at PT. Delisa Minahasa Manado. Journal of Research Results

[4] MOH RI. 2009. Health Act. Jakarta 
[5] Ministry of Health of the Republic of Indonesia, 2016. Regulation of the Minister of Health of the Republic of Indonesia Number 48 Year 2016 Regarding Occupational Safety and Health Standards for Offices.

[6] Kisworo, Good. 2012. The Relationship Between Motivation, Discipline, and the Work Environment with the Performance of Educators and Education Personnel, Study Centers of Ex-residency Learning Activities in Semarang, Central Java, Yogyakarta. Thesis. UNY

[7] Liang Gie, 1996. Modern Office Administration. Yogyakarta: Liberty Yogyakarta

[8] Mardiana, 2005, Production Management, Jakarta: Publisher IPWI Issuing Agency

[9] Mardiasma., 2009, Public Sector Accounting, Yogyakarta: ANDI

[10] Mangkuprawira, Sjafri, 2003, Strategic Human Resource Management, 2nd Printing, Ghalia, Indonesia

[11] Mondy R Wayne. 2008. Human Resource Management. Jakarta: Erlangga

[12] Muhamad Zainur Roziqin, 2010. Job Satisfaction, Malang: Averroes Press

[13] Nawawi, Hadari.2006. Performance evaluation and management in corporate and industrial environments. Yogyakarta: Gadjah Mada University Press

[14]Nitisemito, Alex S.1996. Personnel Management (Human Resource Management). Jakarta: Ghalia Indonesia

[15]Pabundu, Tika, 2006, Organizational Culture and Corporate Performance Improvement, Jakarta: First Printing, PT Bumi Aksara

[16]Prabu. 2009. Impact of Noise on Health. Yogyakarta: Graha Science 